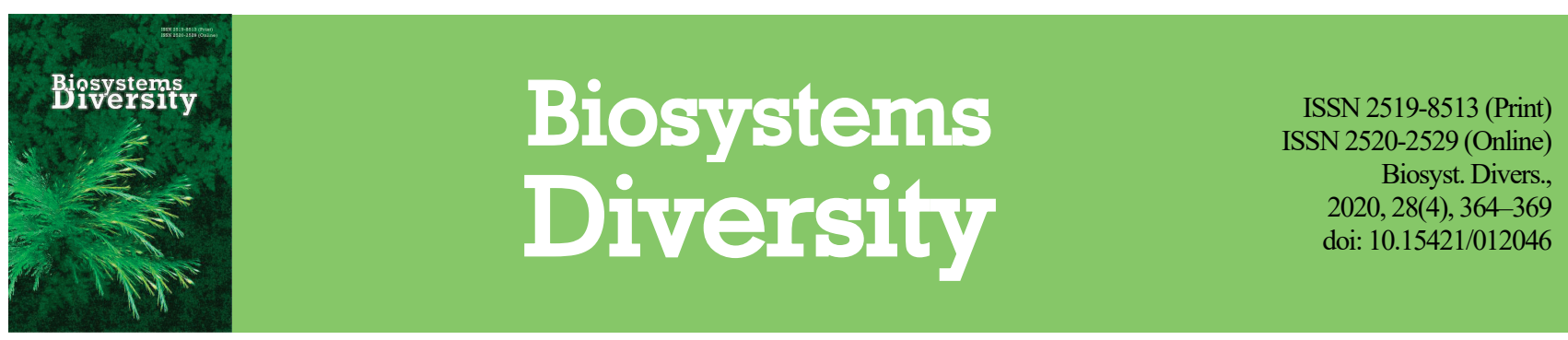

\title{
Rove beetles of the subfamily Aleocharinae (Coleoptera: Staphylinidae) from the Hutsulshchyna National Nature Park
}

\author{
S. V. Glotov*, K. V. Hushtan**** \\ *State Museum of Natural History, National Academy of Sciences of Ukraine, Lviv, Ukraine \\ **Ecological College of Lviv National Agrarian University, Lviv, Ukraine
}

Article info

Received 02.09.2020

Received in revised form 10.10.2020

Accepted 12.10.2020

State Museum of Natural

History, National Academ

of Sciences of Ukraine,

Teatralna st., 18,

Lviv, 79008, Ukraine.

Tel.: +38-068-274-04-06

E-mail:

sergijglotov@gmail.com

Ecological College

of Lviv National

Agrarian University

Zamarstynivska st., 167

Lviv, 79068, Ukraine.

Tel.: + 38-050-370-23-85.

E-mail:

katrinantonyuk@gmail.com
Glotov, S. V., \& Hushtan, K. V. (2020). Rove beetles of the subfamily Aleocharinae (Coleoptera: Staphylinidae) from the Hutsulshchyna National Nature Park. Biosystems Diversity, 28(4), 364-369. doi:10.15421/012046

This work is the first attempt to make up an inventory of the fauna of rove beetles in the Hutsulshchyna National Natural Park (Ukraine, Ivano-Frankivsk Oblast), which was created in 2002 and has an area of 32,271 hectares. The modern territory of the park has never been the object of special scientific research on the fauna of rove beetles of the Aleocharinae subfamily. As a result, information about the finds of representatives of the Aleocharinae subfamily has been obtained from the study of the largest collection of rove beetles in Ukraine, which contains both modern collections and collections of the late 19th and early 20th centuries. The collection was formed by Marian-Aloiz Lomnitski and was further developed and replenished with collections from different parts of Ukraine and the world by several generations of Ukrainian and European entomologists. For the moment, the collection is kept in the funds of the State Museum of Natural History of the National Academy of Sciences of Ukraine and contains more than 1,500 specimens, which belong to more than 300 species and are of great historical and scientific value. As a result of the conducted studies, 30 species belonging to 18 genera are reported for the first time for the fauna of the Hutsulshchyna National Nature Park, of which 4 species (Atheta corvina (Thomson, 1856), Schistoglossa viduata (Erichson, 1837), Leptusa puellaris puellaris (C. Hampe, 1863), Silusa rubra (Erichson, 1839)) are reported for the first time for the territory of Ukraine. The species and specimens (with references, data of their distribution in Europe, as well as substrate and biotope preferences of adults) are listed. The obtained data will later on provide an opportunity to expand the understanding of the distribution of species - specifically for faunal research, as well as for biogeographic modelling.

Keywords: fauna; new species; new records; State Museum of Natural History; Lviv.

\section{Introduction}

Staphylinidae beetles are a widely spread beetle family. At present, there are over 63,500 species in 3,762 genera and 32 subfamilies in the world fauna (Herman, 2001; Klimaszewski et al., 2011). There are over 1100 species of Staphylinidae beetles in the Ukraine fauna (Nikitenko \& Petrenko, 1992). Among them, Aleocharinae is the largest subfamily, which includes about 16,700 valid species in 1,318 genera currently organized in 62 tribes (Klimaszewski et al., 2018). At the same time, according to preliminary estimates, several dozens of thousands of Aleocharinae species have not yet been described (Hlaváč et al., 2009, 2011; Elven et al., 2010, 2012; Assing 2015a, b, c). Representatives of the subfamily, widespread in all natural areas of the planet, inhabit almost all terrestrial natural biotopes, play an active part in the life of natural and artificial biogeocenoses. Larvae and imagoes of Aleocharinae actively inhabit forest cover, plant and animal residues, animal excrement, fungi. A number of progressive adaptive features have led to the emergence of specialized forms that successfully coexist with other animals, living in caves, mammal burrows, in nests of birds as well as those of social insects; and in most cases, without losing the ability to fly (Lipkow \& Betz, 2005; Maruyama \& Parker, 2017). Some members of the genera Aleochara and Alaobia act as endoparasites of larvae and pupae of Diptera and Tenthredinidae, current and potential agents of the biomethod of pest control (Day, 2011). Numerous members of the Aleocharinae subfamily, which are numerous and have a clear timeline for existence in certain natural habitats, are able to respond sensitively to changes in the environment, so they can be used as potential object for bioindication of environmental pollution and monitoring of ecosystems (Klimaszewski et al., 2018). The Hutsulshchyna National Nature Park is located within the Kosiv district of
Ivano-Frankivsk region and covers an area of 32,271 hectares. Altitude distribution in the national park ranges from 350 to $1470 \mathrm{~m}$. The region is characterized by excessive and sufficient moisture, but rainfall is extremely uneven throughout the year and in different areas. Atmospheric humidification of mountainous and foothill areas of Kosiv region is excessive and sufficient.

The predominant type of vegetation is forest formations, which occupy $60 \%$ in the mountains and about $24 \%$ in the foothills. In the lowlying part, deciduous forests prevail, mostly oak forests. In the low tree layer, apart from oaks there are also beech, whereas in more humid places there are ash, birch, elm, and in the underwood there are hazel, hawthorn, elder, and other species. Low-mountain ranges are coated with beech and hornbeam forests with additions of fir, spruce, sycamore maple, birch; higher ranges - with spruce and beech forests as well as spruce forests; and the slopes of the highest ranges - with secondary spruce forests that occur starting from 450-650 m.a.s.l. The park territory is covered with numerous rivers and streams. The largest of them are the Lyuchka, Pistynka, Rybnytsya, Cheremosh, which are right affluents of the River Prut. In the mountainous areas and areas adjacent to the mountains, the rivers form natural barriers, stretches, waterfalls. The main biotope types are presented in Figure 1.

\section{Material and methods}

The collection of the beetles of the subfamily Aleocharinae (Coleoptera, Staphylinidae) is one of the richest and most famous collections of Ukraine. A great part of this collection consists of dry mounted specimens, containing about 2500 specimens, including about 290 species, housed in the State Museum of Natural History (Lviv) of the National Academy of 
Sciences of Ukraine. This material was partly mounted, reordered, and catalogued. In this paper, we present a catalogue of these specimens collected by several generations of entomologists in the early 20 th century from the territory and outskirts of the Hutsulshchyna National Nature Park (according to label data, Fig. 2). Samples were collected from: 1. Kosiv Ivano-Frankivsk Region, Kosivskyi District, Kosiv city, (48.319828 N, $25.097768^{\circ}$ E); 2. Pistin - Ivano-Frankivsk Region, Kosivskyi District, Pistin village $\left(48.356373^{\circ} \mathrm{N}, 25.019105^{\circ} \mathrm{E}\right.$, Fig. 3).

Commonly accepted identification keys were used (Ganglbauer, 1895; Reitter, 1909; Lohse, 1964, 1974; Palm, 1968, 1970, 1972; Strand
\& Vik, 1964, 1965, 1968; Assing et al, 1998; Klimaszewski et al., 2018) as well as the reference material from the museum collections of the Schmalhausen Institute of Zoology, National Academy of Sciences of Ukraine, Kyiv, Ukraine (SIZK), Naturkunde Museum, Berlin, Germany (ZMHB), Naturhistorisches Museum, Vienna, Austria (NMMW), Zoological Museum of Taras Shevchenko National University, Kyiv, Ukraine (ZMTSNH), Zoological Museum of Natural History, Museum of Denmark, Copenhagen, Denmark (ZMUK), and private collection of S. Glotov, Lviv. The list of Staphylinidae was formed in compliance with last nomenclatural corrections (Schülke \& Smetana, 2015).

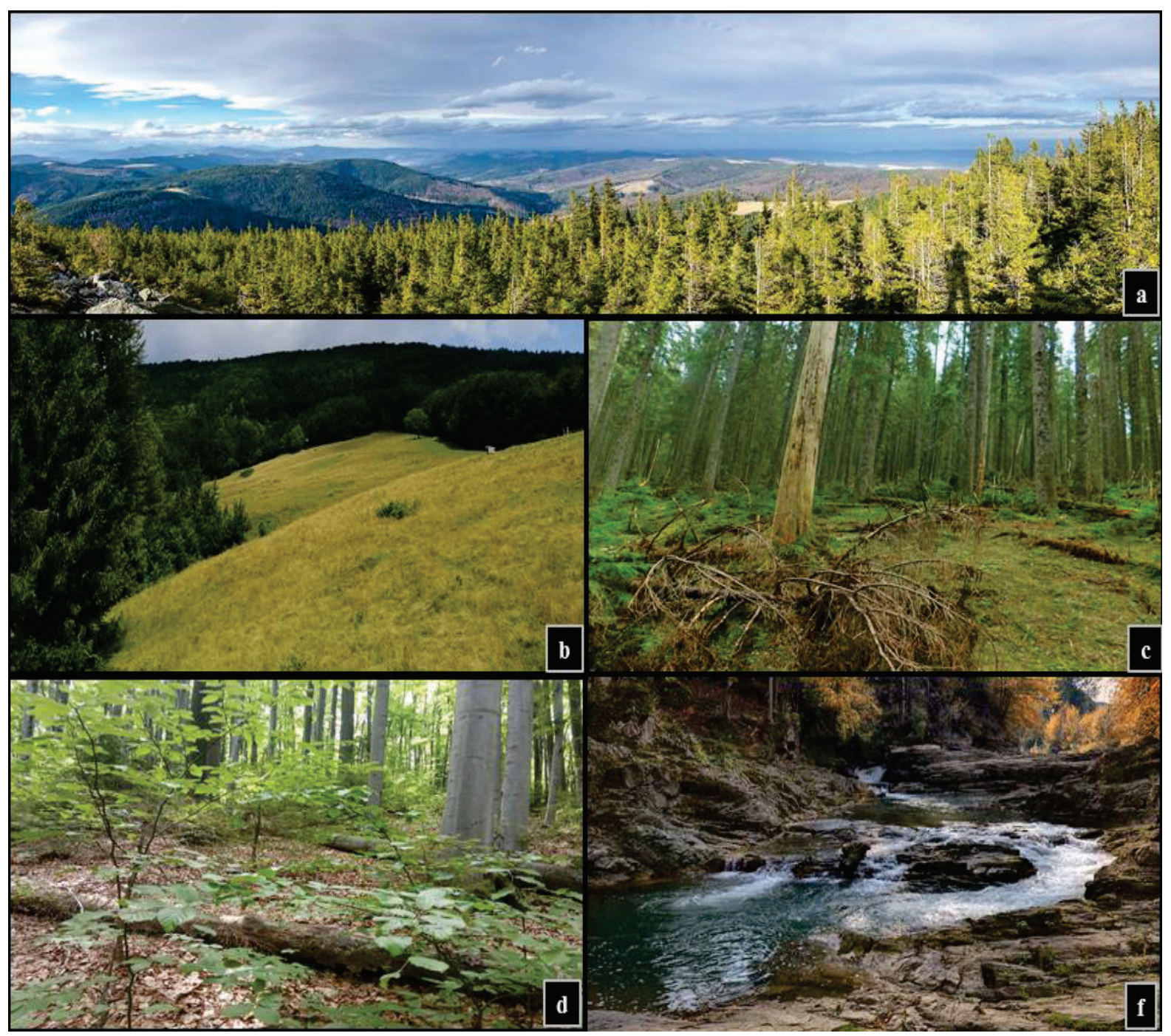

Fig. 1. Different types of biotopes of the Hutsulshchyna National Nature Park (Hutsulshchyna NNP):

$a$ - panorama of the Hutsulshchyna NNP from the mountain Lysyna Kosmatska; $b$ - meadow Rosokhata in the Hutsulshchyna NNP;

$c$-mid-mountain part of the Hutsulshchyna NNP; permanent study area (PSA) No. 5 is situated in spruce primary forest on the mountain Gregit within the similarly-named reserve's natural boundary; $d$-PSA No. 2 in the reserve area of the natural boundary “Khominskyi" of the Starokutske department; this is an association of wood sorrel-sweet-scented bedstraw beech forest for monitoring of the natural beech forest stands which prevail on the territory of the Hutsulshchyna NNP; $f$-waterfalls and rapids of the River Pistynka

\section{Results}

\section{Aleochara intricata Mannerheim, 1830}

Synonymy: Aleochara biguttata Heer, 1839; Aleochara celeris Stephens, 1832; Aleochara cinctipennis Motschulsky, 1858; Aleochara terminata Stephens, 1832; Aleochara croatica Penecke, 1901.

Material examined. Ukraine: Ivano-Frankivsk Prov.: Pistin [Pištyn], date not specified, 1 ex.

Distribution. Palearctic (including Ukraine) (Schülke \& Smetana, 2015).

Biology. The species occurs in forests and in open steppe and meadow areas, in foothills, where it lives in fungi, in animal dung, in animal cadavers, and in decaying plant residues. Adults occur in V-IX (Horion, 1967).

\section{Aleochara brevipennis Gravenhorst, 1806}

Synonymy: Aleochara concolor Stephens, 1832; Aleochara curta C. R. Sahlberg, 1831; Aleochara aurivillosa Jekel, 1873; Aleochara morosa Heer, 1841; Aleochara nigrovillosa Bernhauer, 1901.

Material examined. Ukraine: Ivano-Frankivsk Prov.: Pistin [Pištyn], 28.5. [year not specified], 1 ex.

Distribution. Palearctic region (excluding North Africa, including Ukraine) (Schülke \& Smetana, 2015).

Biology. The species occurs in forests and on open steppe and meadow areas, in foothills and high in the mountains, where it lives in decaying plant residues, in fungi, often under the bark of trees. Adults occur in V-IX (Horion, 1967). 

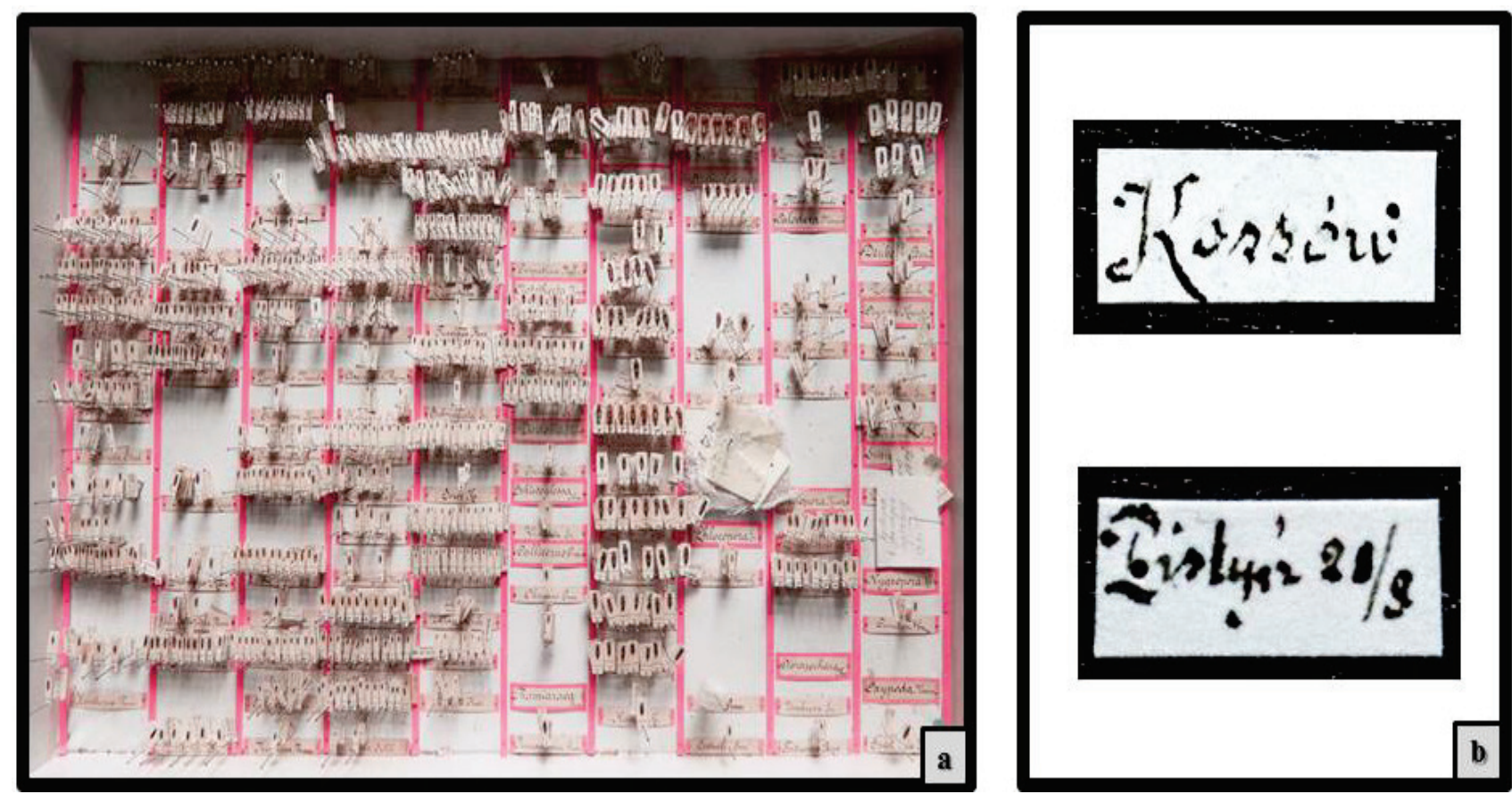

Fig. 2. An example of the arrangement of an insect box $(a)$ and labels $(b)$ from the main collection of the State Museum of Natural History

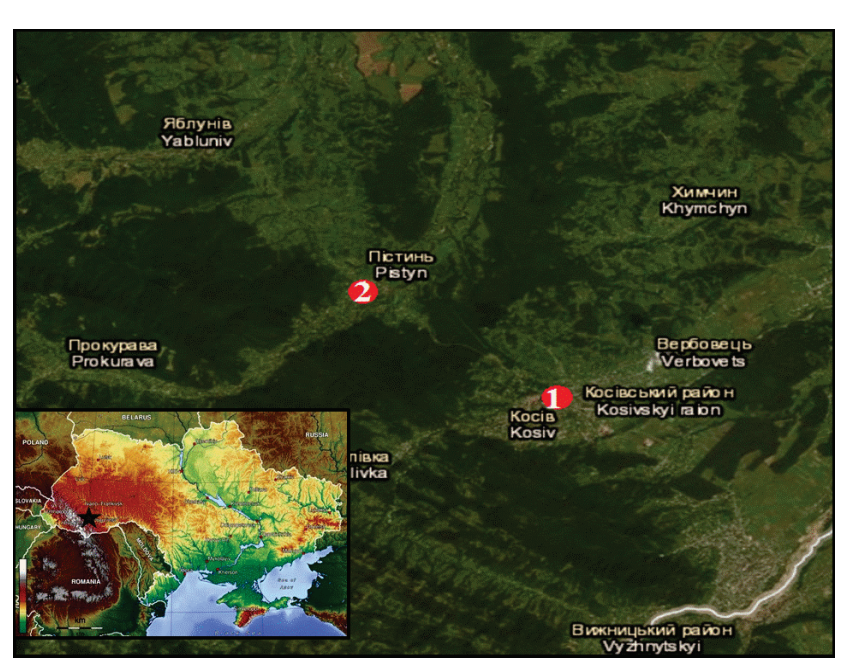

Fig. 3. Map of the study area in the Carpathian Biosphere Reserve (locality numbers see in Materials and methods)

\section{Aleochara fumata Gravenhorst, 1802}

Synonymy: Baryodma affluens Casey, 1906; Aleochara brunnipennis Motschulsky, 1858; Baryodma defecta Casey, 1906; Baryodma lata Thomson, 1860; Aleochara mycetophaga Kraatz, 1856.

Material examined. Ukraine: Ivano-Frankivsk Prov.: Pistin [Pištyn], 20.8. [year not specified], 1 ex.

Distribution. Holarctic (including Ukraine) (Schülke \& Smetana, 2015).

Biology. The species occurs in mixed and deciduous forests, in foothills and high in the mountains, where it lives in fungi, in moss, in rotten wood, in decaying organic residues of plant or animal origin, in animal cadavers, and on effluent tree sap. Adults occur in IV-XI (Roubal, 1930; Horion, 1967; Bogdanov, 1985; Klimaszewski et al., 2011, 2018).

\section{Alianta incana (Erichson, 1837)}

Material examined. Ukraine: Ivano-Frankivsk Prov.: Kosiv [Kossow], date not specified, 1 ex.

Distribution. Europe (including Ukraine), North Africa (Schülke \& Smetana, 2015).

Biology. The species occurs in forests, at foothills, where it lives in forest cover, along the banks of rivers and water bodies, in decaying plant residues. Adults occur in IV-IX (Horion, 1967).

5. Atheta corvina (Thomson, 1856)
Synonymy: Atheta ellimani Bernhauer, 1914; Homalota lepida Kraatz, 1856; Atheta sulcaticeps Scheerpeltz, 1948.

Material examined. Ukraine: Ivano-Frankivsk Prov.: Pistin [Pistyń], date not specified, 1 ex.

Distribution. Europe (including Ukraine), Siberia (Schülke \& Smetana, 2015), reported for the first time from Ukraine and from the Hutsulshchyna National Nature Park.

Biology. The species occurs in mixed and deciduous forests, in the mountains, where it lives in forest cover, decaying organic residues, and in moss. Adults occur in V-IIV (Ganglbauer, 1895).

6. Atheta sodalis (Erichson, 1837)

Synonymy: Atheta biimpressa Scheerpeltz, 1947; Homalota incisa Mulsant \& Rey, 1852; Homalota lithuanica Motschulsky, 1860; Atheta norica Bernhauer, 1941

Material examined. Ukraine: Ivano-Frankivsk Prov.: Kosiv [Kossiw], date not specified, 1 ex.

Distribution. Europe (including Ukraine), Caucasus, Middle Asia, West Siberia (Schülke \& Smetana, 2015).

Biology. The species occurs in mixed and deciduous forests, on open steppe and meadow areas, in foothills and high in the mountains, where it lives in forest cover, in decaying organic residues, in fungi, in rotten wood, and on effluent tree sap (Semenov et al., 2018). Adults occur in V-IIV.

7. Atheta zosterae (Thomson, 1856)

Synonymy: Homalota hodierna Sharp, 1869; Atheta nigrita Fenyes, 1909; Atheta oloriphila Keys, 1933; Gyrophaena rugicollis Hochhuth, 1872; Homalota vicina Kraatz, 1856.

Material examined. Ukraine: Ivano-Frankivsk Prov.: Pistin [Pištyn], date not specified, 1 ex.

Distribution. Europe (including Ukraine), North Africa, Asia Minor, Kazakhstan (Schülke \& Smetana, 2015).

Biology. The species occurs in forests and on open steppe and meadow areas, in foothills and high in the mountains, where it lives in forest cover, in decaying plant residues, in fungi, in burrows of rodents, in ant hills, and on effluent tree sap. Adults occur in V-IX (Bogdanov, 1985; Semenov et al., 2018).

\section{Atheta nigripes (Thomson, 1856 )}

Synonymy: Homalota villosula Kraatz, 1856.

Material examined. Ukraine: Ivano-Frankivsk Prov.: Kosiv [Kossiw], date not specified, 1 ex.

Distribution. Europe (including Ukraine), Mongolia, North Korea (Schülke \& Smetana, 2015).

Biology. Mixed and deciduous forests. Adults occur in VI-VIII. 


\section{Atheta vestita Gravenhorst, 1806}

Synonymy: Aleochara elongata Stephens, 1832; Aleochara quisquiliarum Gyllenhal, 1810; Aleochara sericoptera Stephens, 1832.

Material examined. Ukraine: Ivano-Frankivsk Prov.: Kosiv [Kossiw], date not specified, 1 ex.

Distribution. Europe (including Ukraine), North America (Schülke \& Smetana, 2015).

Biology. The species occurs in forests and on open steppe and meadow areas, in foothills and high in the mountains, on alkalized plots, along the banks of rivers and water bodies, in nearshore areas, where it lives in decaying organic residues. Adults occur in V-VIII (Klimaszeski et al., 2007, 2011).

\section{Hydrosmecta gracilicornis (Erichson, 1839)}

Synonymy: Atheta flavipennis Bernhauer, 1901; Thinoecia libitina Mulsant \& Rey, 1873.

Material examined. Ukraine: Ivano-Frankivsk Prov.: Pistin [Pistyń], date not specified, 1 ex.

Distribution. Central and Southern Europe (including Ukraine), Caucasus (Schülke \& Smetana, 2015).

Biology. Mixed and deciduous forests. Adults occur in VI-VIII (Horion, 1967)

\section{Schistoglossa aubei (Brisout de Barneville, 1860)}

Synonymy: Homalota approximans Eppelsheim, 1886; Atheta breviceps Thomson, 1867; Homalota dispersa Motschulsky, 1860; Schistoglossa impressiceps Scheerpeltz, 1967.

Material examined. Ukraine: Ivano-Frankivsk Prov.: Pistin [Pistyń], date not specified, 1 ex.; same locality but, 31.5.[year not specified], 1 ex.

Distribution. Europe (including Ukraine), Caucasus, East Siberia, Far East (Schülke \& Smetana, 2015).

Biology. The species occurs in mixed and deciduous forests, in foothills, where it lives in forest cover, along the banks of rivers and water bodies, in decaying plant residues. Adults occur in IV-VII (Horion, 1967).

12. Schistoglossa viduata (Erichson, 1837)

Synonymy: Protoskiusa paradoxa Bernhauer, 1900.

Material examined. Ukraine: Ivano-Frankivsk Prov.: Pistin [Pistyń], date not specified, 1 ex.

Distribution. Europe (Schülke \& Smetana, 2015), reported for the first time from Ukraine and from the Hutsulshchyna National Nature Park.

Biology. The species occurs in mixed and deciduous forests, in the mountains, where it lives in forest cover, under stones, and in decaying plant residues. Adults occur in IV-IX (Horion, 1967).

13. Euryusa brachelytra Kiesenwetter, 1851

Synonymy: Euryusa brevipennis Motschulsky, 1858.

Material examined. Ukraine: Ivano-Frankivsk Prov.: Pistin [Pistyń], date not specified, 2 ex.

Distribution. Central Europe (including Ukraine) (Schülke \& Smetana, 2015).

Biology. The species occurs in forests and in open meadow areas as well as on warmed mountain slopes, where it lives mainly in ant colonies: Lasius fuliginosus and L. brunnipes. Adults occur in IV-IX (Roubal, 1930; Horion, 1967; Bogdanov, 1985).

14. Leptusa fumida (Erichson, 1839)

Synonymy: Homalota haemorrhoidalis Heer, 1839; Leptusa helveticola Scheerpeltz, 1972; Homalota morosa Heer, 1841; Homalota pallipes Lucas, 1846; Oxypoda similis Kellner, 1844.

Material examined. Ukraine: Ivano-Frankivsk Prov.: Pistin [Pistyń] [30/20], date not specified, 1 ex.

Distribution. Central and Southern Europe (including Ukraine) (Schülke \& Smetana, 2015).

Biology. The species occurs in mixed and deciduous forests, in foothills and high in the mountains, where it lives in wet places, in forest cover, in moss, in decaying plant residues. Adults occur in III-X (Horion, 1967).

15. Leptusa ruficollis (Erichson, 1839)

Synonymy: Leptusa liebmanni Korge, 1963; Leptusa ludyi Eppelsheim, 1890; Homalota rubricollis Heer, 1841; Leptusa vitalei Bernhauer, 1914.

Material examined. Ukraine: Ivano-Frankivsk Prov.: Kosiv [Kossow], date not specified, 1 ex., leg. Dr. Lokay, Pistin [Pistyń], date not specified, 2 ex.
Distribution. Europe (including Ukraine) (Schülke \& Smetana, 2015).

Biology. The species occurs in deciduous and mixed forests, in foothills, where it lives in fungi. Adults occur in V-VIII (Horion, 1967).

16. Leptusa puellaris puellaris C. Hampe, 1863

Material examined. Ukraine: Ivano-Frankivsk Prov.: Pistin [Pistyń], date not specified, 1 ex., leg. Dr. Lokay.

Distribution. Croatia, Ukraine, reported for the first time from Ukraine and from the Hutsulshchyna National Nature Park.

Biology. The species occurs in deciduous and mixed forests, in foothills, where it lives in decaying plant residues, under stones. Adults occur in VI-VII (Horion, 1967).

17. Anaulacaspis nigra (Gravenhorst, 1802)

Synonymy: Aleochara fracticornis Gravenhorst, 1806; Aleochara picea Gravenhorst, 1802; Falagria pusilla Heer, 1839.

Material examined. Ukraine: Ivano-Frankivsk Prov.: Kosiv [Kos], 18.4.[year not specified], 1 ex.

Distribution. Europe (including Ukraine), Caucasus, Asia Minor, Middle Asia, West Siberia (Schülke \& Smetana, 2015).

Biology. The species occurs in deciduous and mixed forests, in open steppe and meadow areas, in foothills and high in the mountains, on sandy and calciphilous soils as well as on alkalized plots, where it lives in forest cover, in decaying plant residues, in ant hills, and in nests of small mammals. Adults occur in V-VIII (Horion, 1967; Lapeva-Gjonova \& Ilieff, 2012; Assing, 2016).

\section{Brachida exigua (Heer, 1839)}

Synonymy: Encephalus kraatzii Hochhuth, 1872; Homalota notha Erichson, 1839; Gyrophaena pilosa C. Hampe, 1850.

Material examined. Ukraine: Ivano-Frankivsk Prov.: Pistin [Pistyń], [380], date not specified, 1 ex.

Distribution. Europe (including Ukraine) (Schülke \& Smetana, 2015).

Biology. The species occurs in meadows, along forest edges as well as on xerophytic steppe plots, where it lives in forest cover, in moss, in decaying fungi, and in organic residues of plant origin. The beetles are active from July till November, sometimes, they occur in winter during thaw. Adults occur in IV-X (Ganglbauer, 1895; Horion, 1967; Glotov \& Savchenko, 2011, 2013; Glotov, 2012).

\section{Gyrophaena manca Erichson, 1839}

Synonymy: Aleochara angustata Stephens, 1832; Gyrophaena puncticollis Hochhuth, 1872.

Material examined. Ukraine: Ivano-Frankivsk Prov.: Pistin [Pistyń], date not specified, 2 ex.

Distribution. Europe (including Ukraine), Caucasus, Siberia (Schülke \& Smetana, 2015).

Biology. The species occurs in forests and on open steppe plots, in foothills and high in the mountains, where it lives in fungi. Adults occur in III-XI (Glotov et al., 2011a).

20. Gyrophaena minima Erichson, 1837

Material examined. Ukraine: Ivano-Frankivsk Prov.: Pistin [Pistyń], date not specified, 1 ex.

Distribution. Europe (including Ukraine), Asia Minor, Siberia (Schülke \& Smetana, 2015).

Biology. The species occurs in forests and on open steppe plots, in the mountains, where it lives mainly in xylotroph fungi as well as in terraneous gill fungi. Imagoes are active from June till September (Rusch, 1990; Horion, 1967; Glotov et al., 2011a). Adults occur in IV-X (Horion, 1967).

\section{Silusa rubra Erichson, 1839}

Synonymy:Ilyobatesbrevicornis Wasmann, 1902; Silusa rufa Heer, 1839.

Material examined. Ukraine: Ivano-Frankivsk Prov.: Pistin [Pistyń], date not specified, 1 ex.

Distribution. Central and Southern Europe, Asia Minor (Schülke \& Smetana, 2015), reported for the first time from Ukraine and from the Hutsulshchyna National Nature Park.

Biology. The species occurs in deciduous and mixed forests, where it lives in forest cover, in residues of plant origin, in moss, under the bark of trees and under stones along the banks of rivers and water bodies, in fungi. Adults occur in VII-X (Horion, 1967).

\section{Pella similis (Märkel, 1844)}

Material examined. Ukraine: Ivano-Frankivsk Prov.: Pistin [Pistyń], date not specified, 1 ex. 
Distribution. Europe (including Ukraine), Asia Minor (Schülke \& Smetana, 2015).

Biology. The species occurs in open steppe and meadow areas, in deciduous and mixed forests, in floodplain forests, and in artificial stands, where it lives in leafage, in residues of plant origin, and together with ants. Adults occur in IV-VIII (Horion, 1967; Maruyama, 2006).

\section{Apimela mulsanti (Ganglbauer, 1895)}

Synonymy: Homalota pallens Mulsant \& Rey, 1852.

Material examined. Ukraine: Ivano-Frankivsk Prov.: Pistin [Pistyń], date not specified, 1 ex.

Distribution. Central and Southern Europe (including Ukraine), North Africa (Schülke \& Smetana, 2015).

Biology. The species occurs in deciduous and mixed forests, in the mountains, where it lives in forest and meadow cover, in decaying plant residues, under stones, along the banks of rivers and water bodies. Adults occur in V-VI (Horion, 1967).

24. Oxypoda soror Thomson, 1855

Synonymy: Oxypoda flava Kraatz, 1856.

Material examined. Ukraine: Ivano-Frankivsk Prov.: Pistin [Pistyń], date not specified, 2 ex.

Distribution. Europe (including Ukraine) (Schülke \& Smetana, 2015).

Biology. The species occurs in deciduous and mixed forests as well as in open steppe and meadow areas, in foothills and high in the mountains, where it lives in forest and meadow cover, in decaying plant residues, in moss, under stones, along sandy and oozy banks of rivers and water bodies, in nests of mammals (Horion, 1967).

\section{Oxypoda spectabilis Märkel, 1844}

Synonymy: Oxypoda alpina Motschulsky, 1860.

Material examined. Ukraine: Ivano-Frankivsk Prov.: Pistin [Pistyń], date not specified, 1 ex.

Distribution. Europe (including Ukraine) (Schülke \& Smetana, 2015).

Biology. The species occurs in forests as well as in open steppe and meadow areas, in foothills and high in the mountains, where it lives in forest and meadow cover, in decaying plant residues, in fungi, in holes of rodents, in rotten wood of old trees, in moss, in nests of rodents, bumblebees, and wasps (Roubal, 1930; Horion, 1967; Bogdanov, 1985). Adults occur in VI-VII.

\section{Oxypoda togata Erichson, 1837}

Synonymy: Oxypoda atricapilla Maklin, 1846; Oxypoda hospita Grimm, 1845.

Material examined. Ukraine: Ivano-Frankivsk Prov.: Pistin [Pistyń], date not specified, 1 ex.

Distribution. Europe (including Ukraine), North Africa, West Siberia (Schülke \& Smetana, 2015).

Biology. The species occurs in forests, along the banks of rivers and water bodies, where it lives in residues of plant origin, in forest cover, in moss, and together with ants Formica pratensis. Adults occur in III-XI (Horion, 1967)

\section{Tachyusa coarctata Erichson, 1837}

Synonymy: Tachyusa cyanea Kraatz, 1856; Tachyusa nigrita Heer, 1839.

Material examined. Ukraine: Ivano-Frankivsk Prov.: Pistin [Pistyń], date not specified, 1 ex.; Kosiv [Kw], 18.6.[year not specified], 1 ex.

Distribution. Europe (including Ukraine), North Africa, Asia Minor, Siberia, Far East (Schülke \& Smetana, 2015).

Biology. The species occurs in deciduous and mixed forests, in foothills, along the banks of rivers and water bodies, and on swamped plots, where it lives in forest cover and in residues of plant origin. Adults occur in IV-VIII (Horion, 1967; Paśnik, 2006b).

\section{Dasygnypeta velata (Erichson, 1837)}

Synonyms: Calodera flavipes Motschulsky, 1858.

Material examined. Ukraine: Ivano-Frankivsk Prov.: Kosiv [Kossiw], date not specified, 1 ex.

Distribution. Europe (including Ukraine), Siberia (Schülke \& Smetana, 2015)

Biology. The species occurs in deciduous and mixed forests, in the mountains, as well as along the banks of rivers and water bodies, where it lives in sediment loads and decaying plant residues. Adults occur in $\mathrm{V}-$ VII.

\section{Gnypeta carbonaria (Mannerheim, 1830)}

Synonymy: Homalota labilis Erichson, 1839; Atheta paludicola Poppius, 1909

Material examined. Ukraine: Ivano-Frankivsk Prov.: Pistin [Pistyń], date not specified, $1 \mathrm{ex}$.

Distribution. Holarctic (including Ukraine) (Schülke \& Smetana, 2015).

Biology. The species occurs along the banks of rivers and water bodies, in sediment loads as well as in residues of plant origin, in fungi; in the twilight it flies to the light of ultraviolet lamps. Adults occur in VI-VII (Horion, 1967; Klimaszewski et al., 2011).

\section{Ischnopoda leucopus (Marsham, 1802)}

Synonymy: Tachyusa chalybea Erichson, 1840; Aleochara flavitarsis C. R. Sahlberg, 1830.

Material examined. Ukraine: Ivano-Frankivsk Prov.: Pistin [Pistyń], date not specified, 1 ex.

Distribution. Europe (including Ukraine), Asia Minor, Siberia (Schülke \& Smetana, 2015).

Biology. The species occurs in forests, at foothills, where it lives along the banks of rivers and streams, on swamped plots, in forest cover and in residues of plant origin. Adults occur in IV-VIII (Horion, 1967; Paśnik, 2006a)

\section{Discussion}

As a result of the elaboration of the collection from the main stock, 32 specimens of staphylinid beetles belonging to 30 species, 18 genera, were identified for the territory of the Hutsulshchyna National Nature Park and 4 species (Atheta corvina (Thomson, 1856), Schistoglossa viduata (Erichson, 1837), Leptusa puellaris puellaris (C. Hampe, 1863), Silusa rubra (Erichson, 1839)) were recorded in Ukraine for the first time. Among the identified species, 6 species were also noted (Hydrosmecta gracilicornis (Erichson, 1839), Leptusa fumida (Erichson, 1839), Leptusa puellaris puellaris (C. Hampe, 1863), Brachida exigua (Heer, 1839), Dasygnypeta velata (Erichson, 1837), Apimela mulsanti (Ganglbauer, 1895)), which are very rare and poorly studied in the entire area (Lohse, 1974; Pace, 1989; Schülke \& Smetana, 2015).

\section{Conclusion}

On the basis of the research collection, an attempt to inventory the taxonomic composition of the rove beetles of the subfamily Aleocharinae of the Hutsulshchyna National Nature Park has been carried out for the first time. The results of the study of species diversity are not ultimate and can be significantly supplemented and clarified in the future by conducting special research on the territory of the Hutsulshchyna National Natural Park and its surroundings. Nevertheless they fully demonstrate the diversity of the Aleocharinae subfamily in this area. The obtained results can be used in compiling the fauna cadaster of Ukraine, for comparative faunal studies, in analyzing the distribution of species, as well as in biogeographical modelling, in conducting ecological monitoring and forecasting the effects of anthropogenic factors on natural ecosystems.

We would like to take this opportunity and thank V. A. Korneyev and M. Y. Rusin (SIZK), J. Frisch (ZMHB), H. Schillhammer (NHMW), A. Y. Solodovnikov (ZMUC) for the opportunity to work with their respective institutional collections, and their valuable remarks on this manuscript. This work was supported by the National Academy of Sciences of Ukraine (grant 0120U101162). The work was performed within the framework of the scientific topic "Estimation of the biotic diversity of model groups of Arthropoda of the Ukrainian Carpathians with the use of modern information technology".

\section{References}

Assing, V. (2015a). On the Tetrabothrus fauna of China (Coleoptera: Staphylinidae: Aleocharinae: Lomechusini). Linzer Biologische Beiträge, 47(1), 127-143.

Assing, V. (2015b). New species and additional records of Lomechusini from the Palaearctic region, primarily from China (Coleoptera: Staphylinidae: Aleocharinae). Contributions to Entomology, 65(2), 243-262.

Assing, V. (2015c). On the Lomechusini fauna of Vietnam (Coleoptera: Staphylinidae: Aleocharinae). Linzer Biologische Beiträge, 47(2), 1257-1282. 
Assing, V. (2016). Revision of the Anaulacaspis species of the Palaearctic region (Coleoptera: Staphylinidae: Aleocharinae). Contributions to Entomology, Beiträge zur Entomologie, 66(2), 201-255.

Assing, V., Frisch, J., Kahlen, M., Löbl, I., Lohse, G. A., Puthz, V., Schülke, M., Terlutter, H., Uhlig, M., Vogel, J., Willers, J., Wunderle, P., \& Zerche, L. (1998). 23 Familie: Staphylinidae. In: Lucht, W., \& B. Klausnitzer (Eds.). Die Käfer Mitteleuropas. Vierter Supplementband (Bd. 15), Jena.

Bogdanov, Y. A. (1985). Fauna i ekologiya stafilinid Zakarpatya [Fauna and ecology of rove beetles Staphilinids of the Transcarpathia region]. Bureau of Cinema Propaganda, Moscow (in Russian).

Day, J. C. (2011). Parasites, predators and defence of fireflies and glow-worms. Lampyrid, 1, 70-102.

Elven, H., Bachmann, L., \& Gusarov, V. (2010). Phylogeny of the tribe Athetin (Coleoptera: Staphylinidae) inferred from mitochondrial and nuclear sequence data. Molecular Phylogenetics and Evolution, 57(1), 84-100.

Elven, H., Bachmann, L., \& Gusarov, V. (2012). Molecular phylogeny of the Athetini-Lomechusini-Ecitocharini clade of aleocharine rove beetles (Insecta). Zoologica Scripta, 41(6), 617-636.

Ganglbauer, L. (1895). Die Kafer von Mitteleuropa. Die Kafer der osterreichischungarischen Monarchie, Deutschlands, der Schweiz, sowie des französischen und italienischen Alpengebietes. 2. Familienreihe Staphylinoidea. Die Kafer von Mitteleuropa [Die Käfer der österreichisch-ungarischen Monarchie, Deutschlands, der Schweiz, sowie des französischen und italienischen Alpengebietes. 2. Familienreihe Staphylinoidea]. Theil I. Staphylinidae, Pselaphidae Wien: Carl Gerold's Sohn (in German)

Glotov, S. V. (2012). Rove beetles of the genera Agaricochara, Brachida and Encephalus (Coleoptera, Staphylinidae, Aleocharinae) of Ukraine. Vestnik Zoologii, 46(5), 387-393.

Glotov, S. V., \& Savchenko, K. Y. (2011). The rove beetles (Coleoptera: Staphylinidae) of the Reserve 'Kamennye Mogily'. The Kharkov Entomological Society Gazette, 19(2), 5-12.

Glotov, S. V., \& Savchenko, K. Y. (2013). Landscape and biotopical distribution of rove beetles (Coleoptera: Staphylinidae) of the "Kamennye Mogily" Reserve (Ukraine). Caucasian Entomological Bulletin, 9(1), 50-57.

Glotov, S. V., Hushtan, K. V., Kanarsky, Y. V., Hushtan, H. H., \& Rizun, V. B. (2020). Rove beetles (Coleoptera, Staphylinidae) from the Carpathian Biosphere Reserve in collections of State Museum of Natural History (Lviv, Ukraine). Scientific Notes of the State Museum of Natural History, 36, 59-66.

Glotov, S. V., Petrenko, A. A., \& Mateleshko, A. Y. (2011a). Rove beetles of the genus Gyrophaena (Coleoptera, Staphylinidae, Aleocharinae) of Ukraine. Vestnik Zoologii, 45(2), 127-143.

Herman, L. H. (2001). Catalogue of the Staphylinidae (Insecta: Coleoptera). 1758 to the end of the second millenium. Bulletion of the American Museum of Natural History, 265(1-7), 4218.

Hlaváč, P., \& Jászay, T. (2009). A revision of the genus Zyras (Zyras) Stephens, 1835 (Coleoptera, Staphylinidae, Aleocharinae). I. Current classification status and the redefinition of the genus. ZooKeys, 29, 49-71.

Hlaváč, P., Newton, A. F., \& Maruyama, M. (2011). World catalogue of the species of the tribe Lomechusini (Staphylinidae: Aleocharinae). Zootaxa, 3075(1), 151.

Horion, A. (1967). Faunistik der mitteleuropaischen Kafer. Staphylinidae. 3. Habrocerinae bis Aleocharinae (ohne Athetae) [Faunistik der mitteleuropäischen Käfer. Staphylinidae. 3. Habrocerinae bis Aleocharinae (ohne Athetae)]. Uberlingen-Bodensee. P. C. W. Schmidt (in German).

Klimaszewski, J., Assing, V., Majka, C. G., Pelletier, G., Webster, R. P., \& Langor, D. (2007). Records of adventive aleocharine beetles (Coleoptera: Staphylinidae: Aleocharinae) found in Canada. The Canadian Entomologist, 139, 54-79.

Klimaszewski, J., Langor, D., Pelletier, G., Bourdon, C., \& Perdereau, L. (2011). Aleocharine beetles (Coleoptera, Staphylinidae) of the province of Newfoundland and Labrador, Canada. Pensoft Series Faunistica No 98. Pensoft Publishers, Sofia-Moscow.

Klimaszewski, J., Webster, R., Langor, D., Brunke, A. J., Dawies, A., Bourdon, C., Labrecque, M., Newton, A. F., Dorval, J. A., \& Frank, J. H. (2018). Aleocharine rove beetles of Eastern Canada (Coleoptera, Staphylinidae, Aleocharinae): A glimpse of megadiversiti. Springer, Cham.

Lapeva-Gjonova, A., \& Ilieff, O. (2012). Ant-associated rove beetles (Coleoptera: Staphylinidae) from Bulgaria. Acta Entomologica Slovenica, 20(1), 73-84.
Lipkow, E., \& Betz, O. (2005). Staphylinidae and fungi [Staphylinidae and fungi]. Faunistisch Okologische Mitteilungen, 8, 383-411 (in German)

Lohse, G. A. Band 5, Staphylinidae II (Hypocyphtinae und Aleocharinae) [Family Staphylinidae II (Hypocyphtinae und Aleocharinae) Pselaphidae]. In: Freude, H., Harde, K. W., \& Lohse, G. A. (1974). Die Kafer Mitteleuropas. Goecke et Evers Verlag, Krefeld. 5(1) (in German).

Lohse, G. A. Family Staphylinidae I (Micropeplinae bis Tachyporinae). 4 (1) [Family Staphylinidae I (Micropeplinae bis Tachyporinae). 4 (1)]. In: Freude, H., Harde, K. W., \& Lohse, G. A. (1964). Die Kafer Mitteleuropas. Goecke et Evers Verlag, Krefeld (in German)

Maruyama, M. (2006). Revision of the Palearctic species of the myrmecophilous genus Pella (Coleoptera, Staphylinidae, Aleocharinae). National Science Museum Monographs, 32(1-4), 1-207.

Maruyama, M., \& Parker, J. (2017). Deep-time convergence in rove beetle symbionts of army ants. Current Biology, 27, 920-926.

Newton, A. F., \& Thayer, M. K. (1995). Protopselaphinae new subfamily for Protopselaphus new genus from Malaysia, with a phylogenetic analysis and review of the Omaliine group of Staphylinidae including Pselaphidae (Coleoptera). In: Pakaluk, J., \& Ślipiński, S. A. (Eds). Biology, phylogeny, and classification of Coleoptera: Papers celebrating the 80th birthday of Roy A. Crowson. Vol. 1. Muzeum i Instytut Zoologii PAN, Warszawa. Pp. 219-320.

Nikitenko, G. N., \& Petrenko, A. A. (1992). Zhuki-stafiliinidy Coleoptera, Staphylinidae) plodovykh sadov Ukrainy [Staphylinidae beetls (Coleoptera, Staphylinidae) of fruit gardens of Ukraine]. NAS of Ukraine, Kiev (in Russian).

Pace, R. (1989). Monografia del genere Leptusa Kraatz (Coleoptera, Staphylinidae). Memorie del Museo Civico di Storia Naturale di Verona (II Serie) Sezione Scienze della Vita (A: Biologica), 8, 11-307.

Palm, T. (1968). Svensk Insektfauna. 9. Skalbaggar. Coleoptera. Kortvingar: Fam. Staphylinidae. Underfam. Aleocharinae (Deinopsis - Trichomica) [Svensk Insektfauna. 9. Skalbaggar. Coleoptera. Kortvingar: Fam. Staphylinidae. Underfam. Aleocharinae (Deinopsis - Trichomica)]. Stockholm. Vol. 5(51) (in Swedish).

Palm, T. (1970). Svensk Insektfauna. 9. Skalbaggar. Coleoptera. Kortvingar: Fam. Staphylinidae. Underfam. Aleocharinae (Atheta) [Svensk Insektfauna. 9. Skalbaggar. Coleoptera. Kortvingar: Fam. Staphylinidae. Underfam. Aleocharinae (Atheta)]. Stockholm. Vol. 6(52), 117-296 (in Swedish).

Palm, T. (1972). Svensk Insektfauna. 9. Skalbaggar. Coleoptera. Kortvingar: Fam. Staphylinidae. Underfam. Aleocharinae (Aleuconota - Tinotus) [Svensk Insektfauna. 9. Skalbaggar. Coleoptera. Kortvingar: Fam. Staphylinidae. Underfam. Aleocharinae (Aleuconota - Tinotus)]. Stockholm. Vol. 7(53), 301-467 (in Swedish)

Paśnik, G. (2006a). Taxonomy and phylogeny of the world species of the genus Ischnopoda Stephens, 1837 (Coleoptera, Staphylinidae: Aleocharinae). Zootaxa, 1179, 1-96.

Paśnik, G. (2006b). A revision of the world species of the genus Tachyusa Erichson, 1837 (Coleoptera, Staphylinidae: Aleocharinae). Zootaxa, 1146, 1-152.

Reitter, E. (1909). Fauna Germanica. Die Käfer des Deutschen Reiche. Nach der analytischen Methode bearbeitet. Stuttgart: K. G. Lutz, 2 (in Russian).

Roubal, J. (1930). Katalog Coleopter (brouku) Slovenska a Podkarpatska [Catalogue of Coleoptera of Slovenia and Podkarpatia]. Šafárikova, Bratislava, Státní tiskárna, Praha (in Slovak).

Schülke, M., \& Smetana, A. (2015). Staphylinidae Latreille, 1802. In: Löbl, I., \& Löbl, D. (Eds.). Catalogue of Palaearctic Coleoptera. Vol. 1 \& 2. Hydrophiloidea-Staphylinoidea, revised and updated edition. Brill, Leiden \& Boston. Pp. 304-1134.

Semenov, V. B., Egorov, L. V., \& Vinogradova, E. Y. (2015). Annotirovannyi spisok stafilinid (Insecta, Coleoptera, Staphylinidae) Chuvashskoi Respubliki. [The staphylinid beetles (Insecta, Coleoptera, Staphylinidae) annotated checklist of the Chuvash Republic. Novoe Vremya, Cheboksary (in Russian).

Strand, A., \& Vik, A. (1964). Die genitalorgane der nordischen Arten der Gattung Atheta Thoms. (Col., Staph.). Norsk Entomologisk Tidsskrift, 12(5-8), 327335 (in Norwegian).

Strand, A., \& Vik, A. (1965). Die genitalorgane der nordischen Arten der Gattung Oxypoda Mannh. (Col., Staphylinidae). Norsk Entomologisk Tidsskrift, 13(3), 169-175 (in Norwegian).

Strand, A., \& Vik, A. (1968). Die Genitalorgane der Nordischen Arten der Gattung Aleochara Grav. (Col., Staphylinidae). Norsk Entomologisk Tidsskrift, 15, 105-110 (in Norwegian). 